\title{
Genotoxic and Antigenotoxic Properties of Calendula officinalis Extracts in Mice Treated with Methyl Methanesulfonate
}

\author{
Daniela Dimer Leffa ${ }^{1}$, Raquel da Rosa ${ }^{1}$, Bruna Pazini Munhoz ${ }^{1}$, Andréia de Araújo Martins Mello ${ }^{1}$, \\ Fernanda Dagostim Mandelli ${ }^{2}$, Patrícia de Aguiar Amaral ${ }^{2}$, Ângela Erna Rossatto ${ }^{2}$, \\ Vanessa Moraes de Andrade, ${ }^{2, *}$
}

\author{
${ }^{1}$ Laboratório de Biologia Celular e Molecular (LABIM), Universidade do Extremo Sul Catarinense (UNESC), Criciúma, Santa Catarina \\ State, 3167, Brasil \\ ${ }^{2}$ Laboratório de Estudos Etnofarmacológicos (G-FITO), Universidade do Extremo Sul Catarinense (UNESC), Criciúma, Santa Catarina \\ State, 3167, Brasil
}

\begin{abstract}
Calendula officinalis L. (Asteraceae) is used in the traditional medicine for centuries to treat several diseases. The aim of the present study was to investigate in vivo the genotoxicity/mutagenicity and antigenotoxicity/antimutagenicity potential of the Calendula officinalis L. The CF-1 male mice were treated with ethanolic ( $250 \mathrm{or} 500 \mathrm{mg} / \mathrm{Kg}$ ) or aqueous (90 $\mathrm{mg} / \mathrm{Kg}$ ) extracts of C. officinalis for 2 weeks prior to treatment with saline or methyl methanesulfonate. No genotoxic or mutagenic effect was observed at the doses of ethanolic and aqueous extracts of $C$. officinalis in blood and bone marrow samples from animals after 2 weeks of treatment, analyzed by the Comet assay and Micronucleus test, respectively. In addition, ethanolic extracts in both doses $(250$ or $500 \mathrm{mg} / \mathrm{Kg})$ and aqueous extracts $(90 \mathrm{mg} / \mathrm{Kg})$ of this plant showed an antigenotoxic effect by Comet assay, repairing the DNA damage caused by MMS. At the Micronucleus test only aqueous extract of $C$. officinalis revealed a protector effect to genetic material. These results suggest that all the extracts of $C$. officinalis contained protective substances that decreasing damage to genetic material. Despite this protective or antigenotoxic effect from this plant, it should be used with caution by the population.
\end{abstract}

Keywords Calendula Officinalis, Comet Assay, Micronucleus Test, Genotoxicity, Antigenotoxicity

\section{Introduction}

The search of natural products for cancer therapy represents an area of great interest in which plants had been the most important source. Furthermore, the study of plant compounds origin has generated great interest in the fields of food and medicine since many phytochemicals with different pharmacological properties have shown responses for the prevention or treatment of different diseases[1].

The correct use of plants by the general population requires the use of medicinal plants selected for their efficacy and safety, based on folk tradition or validated scientifically[2]. The use of herbal infusions to cure different types of diseases is very common in Brazilian folk medicine, and frequently replaces modern medicine. The diversity of plant species in Brazil is a potential source of biologically active compounds whose effects on human health or in the genetic material are often unknown. However, not all species are

* Corresponding author:

vmoraesdeandrade@yahoo.com.br (Vanessa Moraes de Andrade)

Published online at http://journal.sapub.org/als

Copyright (C) 2012 Scientific \& Academic Publishing. All Rights Reserved harmless to human health, and some may present toxic and/or mutagenic substances in their phytochemical composition[3-5]. On the other hand, a protective action of phytochemical compounds on genetic material has been reported, leading to its repair or to preserving its integrity[4; $6 ; 7]$.

The search for bioactive products those are both effective and non-toxic in the prevention and/or treatment of cancers and other diseases is an important research line. In this manner, Calendula officinalis L. (Asteraceae), also known as marigold, is an aromatic plant with yellow or orange flowers that are used to make herbal preparations. This annual herb native to the Mediterranean region is cultivated in Europe and America for ornamental and medicinal purposes and has been used in traditional medicine for centuries to treat several internal and external inflammatory conditions, gastric and duodenal ulcers and haemorrhoids[8].

Its beneficial activity is related to the content of various secondary metabolites such flavonoids (including lutein, quercetin, protocatechuic acid, etc.), triterpenoids (including faradiol, oleanolic acid, beta-amyrin, calenduladiol, etc.), and the alkaloid narcissi[9]. Flowers also are rich in carotenoids of which flavoxanthin has been reported to be pre- 
sent at $28.5 \%$ of total carotenoids followed by luteoxanthin[10]. Flowers are also found to contain lycopene and $\mathrm{b}$-carotene. Coumarins are also an active ingredient in $\mathrm{Ca}$ lendula officinalis[11].

In the last decade, there was increased interest in the antioxidant properties of $C$. officinalis extracts (infusions and tinctures) because of its rather high polyphenol and carotenoid content[11-13]. However, the protective effect of $C$. officinalis extracts against DNA damage has just studied in vivo in one study[13].

The antitumoral and antimutagenic properties of some components of $C$. officinalis have been described[15; Jiménez-Medina et al. 2006; 13). Jiménez-Medina et al. (2006) have studied the aqueous extract of $C$. offinalis in order to measure its anti-tumor and immunomodulatory activities in vitro. They found that the extract showed a potent inhibition of tumor cell proliferation when tested on a wide variety of human and murine tumor cell lines. In relation to antigenotoxic studies, Pérez-Carreón et al.[15] have analyzed whether $C$. officinalis extracts induce unscheduled DNA synthesis (UDS) in rat liver cell cultures, and if these extracts can reverse diethylnitrosamine (DEN)-induced UDS. They found that both aqueous and ethanolic extract showed complete reversion of the DEN effect. In another work, Frankic et al.[13] evaluated the protective effect of $C$. officinalis propylene glycol extracts against oxidative DNA damage and lipid peroxidation induced by high polyunsaturated fatty acid (PUFA) intake in young growing pigs. The results showed an effective DNA protection from oxidative damage induced by PUFA. Nevertheless, a genotoxic effect has been reported of a fluid extract at concentrations from 0.1 to 1.0 $\mathrm{mg}$ of solid/ $\mathrm{mL}$ in the mitotic segregation assay of the heterozygous diploid D-30 of Aspergillus nidulans although the same extracts were not mutagenic in the Salmonella/microsome assay at concentrations of 50 to 5000 $\mu \mathrm{g} /$ plate $( \pm \mathrm{S} 9)$, and in the mouse bone marrow cells micronucleus test, where the extract was dosed orally up to $1 \mathrm{~g} / \mathrm{kg}$ for two days were not genotoxic either[16].

Culturally, the consumption of $C$. officinalis in Brazil is by means of the teas and infusions, however the use of $C$. officinalis by oral route in humans needs a safety evaluation for this route of administration. Available data are insufficient to support the safety of $C$. officinalis extract by oral route. Thus, considering the strong therapeutic use of $C$. officinalis, this study aimed to investigate the mutagenic/antimutagenic and genotoxic/antigenotoxic activity of aqueous and ethanolic extracts of $C$. officinalis utilizing the Micronucleus Test and the Comet assay.

\section{Material and Method}

\subsection{Identification of Plant Material and Extract Prepa- ration}

Aerial parts of C. officinalis, family Asteraceae, were collected in Grão Pará, SC, Brazil in September 2008. A voucher specimen (number CRI 7379) of C. officinalis was deposited at Herbarium Pe. Dr. Raulino Reitz, Universidade do Extremo Sul Catarinense, Criciúma, SC, Brazil. The aerial parts were allowed to dry under air circulation $\left(40^{\circ} \mathrm{C}\right)$ for 3 days. The ethanolic extract was obtained according to the methodology proposed by Farmacopéia Brasileira[17]. The ethanolic extract was prepared by soaking $200 \mathrm{~g}$ of the dried pharmacogen (ground in a knife mill) in $1000 \mathrm{~mL}$ of solvent (water-alcohol solution of ethanol $45 \%$ ) for about 21 days at room temperature, protected from light, with occasional agitation (once a day) and no renewal of liquid extractor. After, the liquid was strained with the aid of gauze and then filtered on filter paper, and completed the volume to $1000 \mathrm{~mL}$ with the same solvent. Then, the extract was evaporated to dryness under reduced pressure. This dry extract was then diluted in water to give two different doses to be tested (250 and $500 \mathrm{mg} / \mathrm{kg}$, adapted by Lagarto et al.[18]. The aqueous extract was obtained by infusion of $0.53 \mathrm{~g}$ of dry pharmacogen in $20 \mathrm{~mL}$ of distilled hot water, just before use. The dose of the aqueous extract $(90 \mathrm{mg} / \mathrm{kg})$ was based on the calculation of total solids.

\subsection{Phytochemical Screening}

The phytochemical analysis (flavonoids, tannins, anthraquinones, alkaloids, saponins, coumarins and cardiac glycosides) of the aerial parts of $C$. officinalis was carried out according to the methods described by Harborn[19]. The thin layer chromatography analyses were performed following systems and developers indicated by Wagner and Bladt[20], and the aluminum chloride colorimetric method was used for flavonoids quantitative determination[17]. Each plant extracts $(0.5 \mathrm{~mL}$ of $1: 10 \mathrm{~g})$ in methanol were separately mixed with $1.5 \mathrm{~mL}$ of methanol, $0.5 \mathrm{~mL}$ of $2 \%$ aluminum chloride, $0.1 \mathrm{~mL}$ of $1 \mathrm{M}$ potassium acetate and $2.8 \mathrm{~mL}$ of distilled water. It remained at room temperature for $30 \mathrm{~min}$; the absorbance of the reaction mixture was measured at $425 \mathrm{~nm}$ with biospectro Model SP-22 UV/Visible spectrophotometer.

\subsection{Animals and Treatments}

CF-1 male mice (weighing $30-45 \mathrm{~g}$ ) were obtained from the breeding colonies of the Universidade do Extremo Sul Catarinense, UNESC, Criciúma, SC, Brazil. The animals were kept in plastic cages in an experimental room under controlled conditions of temperature $\left(22 \pm 2^{\circ} \mathrm{C}\right)$, humidity $(55 \pm 10 \%), 12$-h light/dark cycle and with ad libitum access to diet and water. The animals were randomized at the beginning of the experiment. The study design was approved by the Animal Ethical Committe of UNESC (protocol number 043/2008) and the experiments were conducted in accordance with the ethical principles of the Brazilian College of Animal Experimentation - COBEA.

Methyl methanesulfonate (MMS; Sigma-Aldrich), a monofunctional sulfurcontaining compound commonly used as a solvent and as a catalyst for polymerization, alkylation and esterification reactions[21], was used to induce muta- 
tions and DNA damage for the antimutagenic/antigenotoxic evaluations. MMS was diluted in $0.9 \% \mathrm{NaCl}$ just before use. The route of exposure was by intraperitoneal (ip) injection of $40 \mathrm{mg} / \mathrm{kg}$ b.w.[22].

\subsection{Experimental Design}

The evaluation of DNA damage or protection by the aqueous and ethanolic extracts of $C$. officinalis were performed according the protocol developed by Azevedo et al.[23] with adaptations as follows (see Figure 1): Initially, the mice were divided into 7 groups, with 5 animals per group. In group 1, mice received only distilled water (10 $\mathrm{mL} / \mathrm{kg}$ b.w. per day by gavage) for 14 days prior to treatment with $0.9 \% \mathrm{NaCl}$ by intraperitoneal (i.p) injection. Group 2 also received distilled water $(10 \mathrm{~mL} / \mathrm{kg}$ b.w. per day by gavage) for 14 days, but the mice were treated on day 15 with MMS (40 mg/kg b.w.) by i.p. injection. Groups 3 and 4 received ethanolic extract of $C$. officinalis administered orally $(10 \mathrm{~mL} / \mathrm{kg}$ b.w. per day by gavage) prepared as two different doses: $250 \mathrm{mg} / \mathrm{kg}$ (group 3) and $500 \mathrm{mg} / \mathrm{kg}$ (group 4), for 14 days prior to treatment with MMS. Group 5 received only ethanolic extract of $C$. officinalis administered orally $(500 \mathrm{mg} / \mathrm{kg})$ for 14 days prior to a $0.9 \% \mathrm{NaCl}$ i.p. injection on day 15 . Groups 6 and 7 received the aqueous extract of C. officinalis $(90 \mathrm{mg} / \mathrm{kg})(10 \mathrm{~mL} / \mathrm{kg}$ b.w. per day by gavage) for 14 days prior to a $0.9 \% \mathrm{NaCl}$ or $\mathrm{MMS}$ $(40 \mathrm{mg} / \mathrm{kg})$ i.p. injection on day 15 . The mice were killed by cervical dislocation, $24 \mathrm{~h}$ after treatment, for the evaluation of micronucleated polychromatic erythrocytes (MNPCEs) in the bone marrow. The Comet assay was performed on all groups and samples of peripheral blood were collected from mouse tail tips by means of a small incision $4 \mathrm{~h}$ after treatment with MMS.

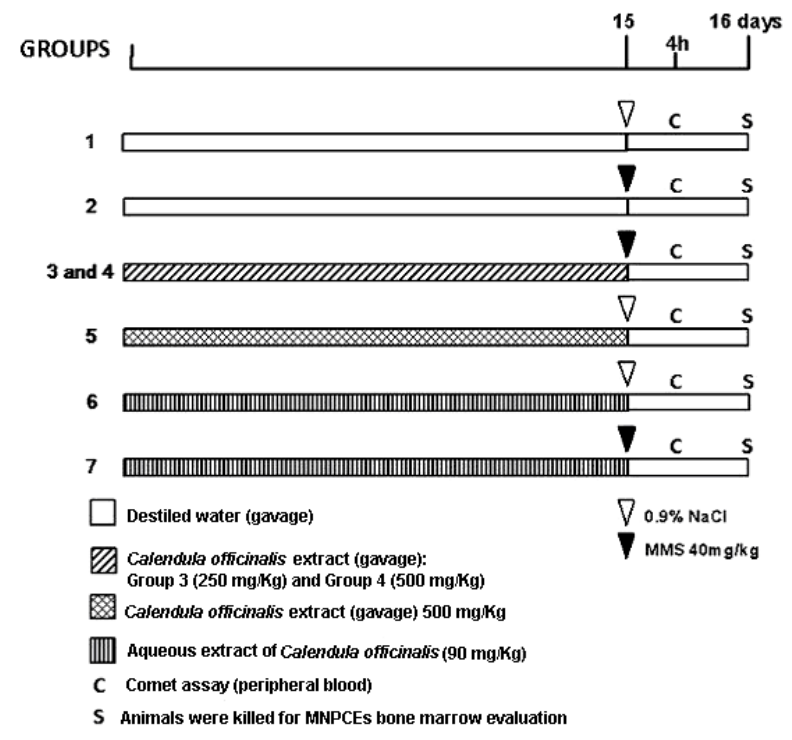

Figure 1. Study trial to test the antimutagenicity and antigenotoxicity of Calendula officinalis extract on the mutagen-induced micronulei and comet assay effects

\subsection{Micronucleus Test}

The micronucleus assay was performed according to the US Environmental Protection Agency Gene-Tox Program[24]. Bone marrow from both femurs was suspended in foetal calf serum and smears on clean glass slides were prepared. Slides were air-dried, fixed in methanol, stained in $10 \%$ Giemsa and coded for a blind analysis. Two thousand polychromatic erythrocytes were analyzed per mouse. To detect possible cytotoxic effects, the proportion of PCE and NCE (normochromatic erythrocytes) in 200 erythrocytes/animal was calculated. The slides were scored blindly using a light microscope with a 100x immersion objective.

\subsection{Comet Assay}

Single Cell Gel Electrophoresis or Comet assay is a highly sensitive method for the assessment of DNA damage formation and repair both at clinically relevant and low doses. The alkaline Comet assay was performed as described by Singh et al.[25]. Peripheral blood samples were collected by the tail from each animal in heparinized microtubes $4 \mathrm{~h}$ after the MMS treatment. Briefly, $5 \mu \mathrm{L}$ of whole blood was embedded in a layer consisting of 95 ųL of $0.75 \%$ low melting point agarose gel on frosted slides and immersed in a lysis buffer $(2.5 \mathrm{M} \mathrm{NaCl}, 100 \mathrm{mM}$ EDTA, and $10 \mathrm{mM}$ Tris [pH $10.0-10.5$ ] with freshly added $1 \%$ Triton X-100 and $10 \%$ dimethyl sulfoxide) for a minimum of $1 \mathrm{~h}$ and a maximum of 1 week. Subsequently, the slides were incubated in freshly made alkaline buffer $(300 \mathrm{mM} \mathrm{NaOH}$ and $1 \mathrm{mM}$ EDTA, $\mathrm{pH}>13)$ for $20 \mathrm{~min}$. The nuclei were electrophoresed for 20 min at $25 \mathrm{~V}(0.90 \mathrm{~V} / \mathrm{cm})$ and $300 \mathrm{~mA}$, and then the alkali was neutralized with $0.4 \mathrm{M}$ Tris ( $\mathrm{pH} 7.5)$. After neutralization, the slides were fixed $(15 \% \mathrm{w} / \mathrm{v}$ trichloroacetic acid, $5 \% \mathrm{w} / \mathrm{v}$ zinc sulfate, $5 \%$ glycerol), washed in distilled water and dried overnight. The gels were re-hydrated for $5 \mathrm{~min}$ in distilled water, and then stained for $15 \min \left(37^{\circ} \mathrm{C}\right)$ with a solution containing the following sequence: $34 \mathrm{~mL}$ of Solution B ( $0.2 \% \mathrm{w} / \mathrm{v}$ ammonium nitrate, $0.2 \% \mathrm{w} / \mathrm{v}$ silver nitrate, $0.5 \%$ $\mathrm{w} / \mathrm{v}$ tungstosilicic acid, $0.15 \% \mathrm{v} / \mathrm{v}$ formaldehyde, $5 \% \mathrm{w} / \mathrm{v}$ sodium carbonate) and $66 \mathrm{~mL}$ of Solution A (5\% sodium carbonate). The staining was stopped with $1 \%$ acetic acid and then the gels were air-dried[26]. The extent of the DNA damage was assessed using the Collins' visual classification method[27]. Cells were scored from 0 (undamaged) to 4 (maximally damaged) according to tail intensity (size and shape), resulting in a single DNA damage score (damage index) for each sample and, consequently, for each group. Thus, a damage index (DI) of the group could range from 0 (completely undamaged) 100 cells $\times 0$ ) to 400 (maximum damage) 100 cells $(\times 4)$. The percentage damage frequency (DF) was calculated for each sample on the basis of the number of cells with a tail versus with no tail.

\subsection{Statistical Analysis}

The normality of variables was assessed using the Kolmogorov-Smirnov test. For the micronucleus test and Comet assay, we performed multiple pair-wise comparisons between the experimental groups and the positive and negative 
controls using Student's t-test at a significance level of 0.05 . The statistical package used was BioEstat 5.0. The percentage of reduction in the frequency of MMS induced DNA damage was calculated according to Waters et al.[28] and Azevedo et al.[29].

\section{Results and Discussion}

Table 1 shows the phytochemical analyses of $C$. officinalis extract. The analyses indicated the presence of fenolic compounds, tannins, flavonoids, alkaloids and coumarins. Yet, other secondary metabolites such as anthraquinones and saponins were not detected.

Table 1. Phytochemical screening

\begin{tabular}{|c|c|}
\hline Test & Calendula officinalis \\
\hline \multicolumn{2}{|l|}{ Phenolic compounds } \\
\hline$C O-A E+K O H \quad 3 \%$ & + \\
\hline $\mathrm{Co}-\mathrm{AE}+\mathrm{FeCl}_{3} 1 \%$ & + \\
\hline \multicolumn{2}{|l|}{ Tannins } \\
\hline Co-AE + gelatin & + \\
\hline $\mathrm{Co}-\mathrm{AE}+\mathrm{FeCl}_{3} 3 \%$ & + \\
\hline \multicolumn{2}{|l|}{ Flavonoids qualitative } \\
\hline $\mathrm{Co}-\mathrm{AE}+\mathrm{MgO} / \mathrm{HCl}$ & + \\
\hline \multicolumn{2}{|l|}{ Flavonoids quantitative $U V 425 \mathrm{~nm}$} \\
\hline Co-ME & $0.681(0,2-0,9 \%)$ \\
\hline \multicolumn{2}{|l|}{ Alkaloids } \\
\hline Co-AE + Mayer's Reagent & + \\
\hline Co-AE + Bertrand's Reagent & - \\
\hline Co-AE + Dragendorff's Reagent & + \\
\hline Co-AE + Bouchard's Reagent & + \\
\hline \multicolumn{2}{|l|}{ Antraquinones } \\
\hline $\mathrm{Co}-\mathrm{AE}+\mathrm{KOH} 3 \%$ & - \\
\hline \multicolumn{2}{|l|}{ Coumarins } \\
\hline $\mathrm{Co}-\mathrm{EE}+\mathrm{KOH} / \mathrm{UV} 365 \mathrm{~nm}$ & + \\
\hline \multicolumn{2}{|l|}{ Saponins } \\
\hline $\mathrm{Co}-\mathrm{AE}+\mathrm{HCl}$ (persistent foam) & - \\
\hline
\end{tabular}

Co-AE - water extract./ Co-ME - methanolic extract/ Co-EE - ethanolic extract / (-)negative / (+) positive

The Comet assay results are summarized in Table 2. Results from the analyses of DNA damage in both parameters of the Comet assay (damage index and damage frequency) in the peripheral blood of mice indicated that the ingestion of water (negative control), ethanolic extract of C. officinalis $250 \mathrm{mg} / \mathrm{kg}$ and $500 \mathrm{mg} / \mathrm{kg}$ (Co-EE), and aqueous extract of C. officinalis $90 \mathrm{mg} / \mathrm{kg}$ (Co-AE) by the animals during the 15 days of treatment did not present any statistically significant difference. The analyses have demonstrated low values of damage index (DI) and damage frequency (DF), showing that these beverages do not have a genotoxic effect on peripheral blood cells of mice.

When the antigenotoxicity of Co-EE at the two doses and the $\mathrm{Co}-\mathrm{AE}$ were evaluated, significant decreases in MMS-induced DNA damage were observed in mice receiving $250 \mathrm{mg} / \mathrm{kg}$ and $500 \mathrm{mg} / \mathrm{kg}$ of Co-EE at DI and DF and Co-AE $100 \mathrm{mg} / \mathrm{kg}$ at DI and DF.

The reduction in DNA damage with the pre-treatment with $250 \mathrm{mg} / \mathrm{kg}$ of Co-EE was of $57.14 \%(\mathrm{P}<0.001$ Student's t-test) for DF and $66.5 \%(\mathrm{P}<0.001$, Student's t-test $)$ for DI in relation to the positive control (MMS $40 \mathrm{mg} / \mathrm{kg}$ ). Concerning the $500 \mathrm{mg} / \mathrm{kg}$ of Co-EE, the reduction values was of $54.5 \%(\mathrm{P}<0.05$, Student's t-test $)$ and $61.86 \%(\mathrm{P}<0.01$ Student's t-test) for DF and DI, respectively. In addition, the analyses of DNA damage after pre-treatment with de Co-AE indicated that this kind the extract diminish the DNA damage chemically induced by MMS in $58.44 \%(\mathrm{P}<0.001$ Student's t-test) for DF and $77.82 \%$ (P $<0.001$, Student's t-test $)$ for DI at single dose of $90 \mathrm{mg} / \mathrm{kg}$ (Table 2).

Table 2. Detection of lesions in DNA (mean \pm SD) using the comet assay (DF and DI) in peripheral blood cells of mice exposed to methyl methanesulfonate (MM mg/kg) and different doses of C. officinalis. Were utilized 5 animals/group

\begin{tabular}{|l|c|c|c|c|}
\hline \multicolumn{1}{|c|}{ Treatments } & DF & $\begin{array}{c}\text { \% of } \\
\text { reduction }\end{array}$ & DI & $\begin{array}{c}\% \text { of } \\
\text { reduction }\end{array}$ \\
\hline $\begin{array}{l}\text { Negative Con- } \\
\text { trol }\end{array}$ & $20.0 \pm 0.0^{\mathrm{c}}$ & - & $\begin{array}{c}15.0 \pm \\
4.5^{\mathrm{c}}\end{array}$ & - \\
\hline Positive Control & $96.8 \pm 6.10$ & - & $\begin{array}{c}271.8 \pm 54 \\
.71\end{array}$ & - \\
\hline $\begin{array}{l}\text { Co-EE } \\
250 \mathrm{mg} / \mathrm{Kg}+\end{array}$ & $\begin{array}{c}53.2 \pm \\
6.89^{\mathrm{c}}\end{array}$ & 57.14 & $\begin{array}{c}100.6 \pm 43 \\
.99^{\mathrm{c}}\end{array}$ & 66.5 \\
$\mathrm{MMS}$ & $55.0 \pm$ & 54.5 & $\begin{array}{c}113.5 \pm 73 \\
.33^{\mathrm{b}}\end{array}$ & 61.86 \\
\hline $\begin{array}{l}\mathrm{Co}-\mathrm{EE} \mathrm{500} \\
\mathrm{mg} / \mathrm{Kg}+\mathrm{MMS}\end{array}$ & $8.87^{\mathrm{a}}$ & - & $\begin{array}{c}34.0 \pm 39 . \\
77\end{array}$ & - \\
\hline $\begin{array}{l}\text { Co-EE 500 } \\
\mathrm{mg} / \mathrm{Kg}+\text { saline }\end{array}$ & $25.4 \pm 7.84$ & - & $\begin{array}{c}39.2 \pm 26 . \\
40\end{array}$ & - \\
\hline $\begin{array}{l}\text { Co-AE 90 } \\
\mathrm{mg} / \mathrm{Kg}+\text { saline }\end{array}$ & $29.6 \pm 0.71$ & - & $\begin{array}{c}72.4 \pm 19 . \\
03^{\mathrm{c}}\end{array}$ & 77.82 \\
\hline $\begin{array}{l}\text { Co-AE 90 } \\
\mathrm{mg} / \mathrm{Kg}+\mathrm{MMS}\end{array}$ & $2.93^{\mathrm{c}}$ & 58.44 & \\
\hline
\end{tabular}

$\mathrm{SD}=$ Standard Deviation $; \mathrm{DF}=$ Damage Frequency DI $=$ Damage Index; Negative Control $=\mathrm{NaCl} 0.9 \%$; Positive Control = MMS 40mg $/ \mathrm{kg}$; Co-EE = Ethanolic extract of C. officinalis; Co-AE = Aqueous extract of C. officinalis; ${ }^{\mathrm{a}}$ Values significant in relation to the positive control, $\mathrm{P}<0.05 ;{ }^{\mathrm{b}} \mathrm{P}<0.01$; ${ }^{\mathrm{c}} \mathrm{P}$ $<0.001$ (Student's t-test)

Results from the MN test in bone marrow cells of mice are presented in Table 3.

Table 3. Effects of the different doses of $C$. officinalis extracts pre-treatments (gavage) on the frequencies of MNPCEs (mean \pm SD) in bone marrow of mice after intraperitoneal injection with MMS $40 \mathrm{mg} / \mathrm{kg}$. Were analyzed 1000 cells/slide

\begin{tabular}{|c|c|c|c|}
\hline Treatment & PCE/NCE ratio & MNPCEs & P Values \\
\hline Negative Control & $1.06 \pm 0.02$ & $2.0 \pm 0.0$ & $0.003^{\mathrm{a}}$ \\
\hline Positive Control & $2.31 \pm 0.56$ & $4.4 \pm 1.7$ & - \\
\hline $\begin{array}{c}\text { Co-EE 250mg/Kg + } \\
\text { MMS }\end{array}$ & $2.85 \pm 1.07$ & $4.0 \pm 3.2$ & - \\
\hline $\begin{array}{c}\text { Co-EE 500 mg/Kg + } \\
\text { MMS }\end{array}$ & $2.82 \pm 1.09$ & $3.2 \pm 1.8$ & - \\
\hline $\begin{array}{c}\text { Co-EE 500 mg/Kg + } \\
\text { saline }\end{array}$ & $1.45 \pm 0.30$ & $3.0 \pm 1.2$ & - \\
\hline $\begin{array}{c}\text { Co-AE 90 mg/Kg }+ \\
\text { saline }\end{array}$ & $1.80 \pm 0.32$ & $1.2 \pm 1.8$ & $0.007^{\mathrm{a}}$ \\
\hline $\begin{array}{c}\text { Co-AE 90 mg/Kg }+ \\
\text { MMS }\end{array}$ & $1.59 \pm 0.88$ & $1.2 \pm 1.8$ & $0.007^{\mathrm{a}}$ \\
\hline
\end{tabular}

MNPCE $=$ Micronucleates polychromatic erythrocytes; SD = Standard Deviation; $\mathrm{Co}-\mathrm{EE}=$ Ethanolic extract of C. officinalis; $\mathrm{Co}-\mathrm{AE}=$ Aqueous extract of $\mathrm{C}$. officinalis; Negative Control $=\mathrm{NaCl} 0.9 \%$; Positive Control $=\mathrm{MMS} 40 \mathrm{mg} / \mathrm{kg}$. $\mathrm{PCE}=$ Polychromatic erythrocytes $\mathrm{NCE}=$ Normochromatic erythrocytes. ${ }^{a}$ Values significant in relation to the positive control (Student's t-test)

Our results exposed at the table 3 showed that the negative control group presented significantly lower values when 
compared at positive control group, with $\mathrm{P}=0.003$ (Student's $t$-test). At the micronucleus test in relation of the mutagenicity, water, Co-EE $500 \mathrm{mg} / \mathrm{Kg}$ and Co-AE have demonstrated low values of micronucleated cells, showing that these compounds did not have a mutagenic nor a cytotoxic effect on mouse bone marrow cells i.e., no statistically significant difference in the frequency of MN PCE or the ratio of PCE to NCE among the negative control and the groups that have ingested the beverages could be detected.

When the antimutagenicity of Co-EE and Co-AE were evaluated, significant decrease in the frequency of MMS-induced MNPCE was observed just in mice that received $90 \mathrm{mg} / \mathrm{Kg}$ of Co-AE with $\mathrm{P}=0.007$ (Student's $t$-test). Results from the Co-EE in the doses of 250 and $500 \mathrm{mg} / \mathrm{Kg}$ did not show statistically significant reductions in the frequency of MNPCE (Table 3).

Calendula officinalis Linn. has been employed for a long time in folk therapy. In addition, more than 35 properties have been attributed to decoctions and tinctures of this plant extract[30]. It has been reported to possess many pharmacological activities, which include antioxidant[11] antiinflammatory[31] antibacterial[32], antifungal[33], antiviral[34], anti-genotoxic[15], and antitumoral[35]. Its beneficial activity is related to the content of various secondary metabolites such as polyphenols, carotenoids, triterpenes and essential oils[ $[10 ; 36]$. However, controversial effects have been shown in secondary metabolites such as flavonoids, which acts as an antioxidant and at higher concentrations can act as pro-oxidant [37]. Duarte-Silva et al.[38] found that flavonoids with a structure similar to quercetin are genotoxic to prokaryotic and eukaryotic cells and this depends on their auto-oxidative ability that is promoted by alkaline $\mathrm{pH}$ and by the metabolic system.

Based on these paradigms in the literature, in this study we have tested in vivo the effect of two different aqueous and ethanolic extracts from the natural sources of $C$. officinalis to investigate its antigenotoxic potential in comparison with a well-known DNA double-strand break-inducing agent, MMS[39].

Our first and very important observation was the absence of DNA strand breaks in the Comet assay and the formation of micronuclei induced in mice that have received the two kinds of $C$. officinalis extract, without MMS. In our work, neither the ethanolic nor the aqueous extract presented genotoxic or mutagenic properties in the Comet assay and in the $\mathrm{MN}$ test, respectively. These results are in according with the works mentioned below that not related genotoxicity or mutagenicity in this extracts.

Lagarto et al.[18] studied the acute and subchronic oral toxicities of $C$. officinalis extract in male and female Wistar rats. A single acute $C$. officinalis extract dose of $2000 \mathrm{mg} / \mathrm{kg}$ dissolved in distilled water was administered by oral gavage for acute toxicity. Subchronic doses of 50, 250 and 1000 $\mathrm{mg} / \mathrm{kg} /$ day were administered in drinking water. In the acute study, there were no mortality and signs of toxicity and the subchronic toxicity (after 90 days) of $C$. officinalis extract was low.
Nevertheless, a genotoxic effect has been reported of a $60 \%$ hydroalcoholic flower extract at concentrations from 100 to $1000 \mathrm{~g}$ of solids $/ \mathrm{mL}$ in the mitotic segregation assay of the heterozygous diploid D-30 of Aspergillus nidulans[16], although the same extracts were not mutagenic in the Ames assay, at concentrations of 50-5000 mg/plate with Salmonella typhimurium strains TA1535, TA1537, TA98 and TA100, either with or without the S9 fraction, and in the mouse bone marrow micro-nucleus test, doses up to $1 \mathrm{~g} / \mathrm{kg}$ for 2 days were not genotoxic either[16].

Pérez-Carreón et al.[15] through of the evaluation of the putative genotoxicity of extracts in rat liver cell cultures revealed that $C$. officinalis extracts rich in flavonols act as anti-genotoxic agents in low concentrations against the genotoxic effects of the known carcinogen DEN and induce genotoxicity at high concentrations (three orders of magnitude above the protective concentration).

Concomitant we have tested the effect of these extracts of C. officinalis against a well-known genotoxic compound to investigate its antigenotoxic potential for the possible use in the diseases prevention. So, in this work we investigated not only its genotoxic potential, but also a possible antimutagenic and antigenotoxic effect of $C$. officinalis in vivo against DNA damage induced by MMS, an alkylating agent.

When the protective effect of $C$. officinalis was investigated in peripheral blood cells by the comet assay and in the bone marrow PCE by the MN test, the results clearly indicated that both $C$. officinalis aqueous and ethanolic extract was efficient in reverting antigenotoxic damage (as shown in the comet assay) induced by MMS. However, the ethanolic extract obtained from $C$. officinalis did not exert any protective activity against the DNA damage induced by MMS in the $\mathrm{MN}$ test.

Then, to elucidate the mechanism of antigenotoxic/ antimutagenic action of $C$. officinalis we performed two assays. An antimutagenic effect in the MN test could mainly be due to reduced induction of damage or increased repair; however, the comet assay measures the amount of DNA damage after treatment with a mutagen and thus can indicate if an antigenotoxic effect is due to reduced formation of primary DNA lesions. We were able to show a clear induction of DNA effects by MMS and could demonstrate that this effect can be reduced by pre-treatment of the animals with aqueous and ethanolic extract. In the MN test, the significant reduction was only observed at the single dose of the aqueous extract. Thus, C. officinalis extract prevented MMS-induced DNA lesions. In the pre-treatment, phenolic compounds could have competed as target sites for alkylation. On the other hand, the absence of a protective effect from the ethanolic extract obtained from $C$. officinalis against the frequency of mutations induced by MMS could be due to possible interactions among compounds contained within the extract itself.

We propose that this protective effect is caused by main chemical constituents of $C$. officinalis that contribute to their antioxidant capacity $[9 ; 10]$ include steroids, terpenoids, free and esterified triterpenic alcohols, phenolic acids, flavonoids 
(quercetin, rutin, narcissin, isorhamnetin, kaempferol), and other compounds since many of these phytochemicals have been found in both extracts of this study[40]. This antioxidant effect is associated with the anti-genotoxic and anti-mutagenic proprieties describe in several research that can be exploited for its use against a number of disorders including cardiovascular diseases, inflammation, and can$\operatorname{cer}[11]$.

These results now support the data obtained in vitro and in vivo studies, where low concentrations of $C$. officinalis extracts protected rat liver cell cultures and hepatocytes against the genotoxic effects of $\mathrm{N}$-nitrosodiethylamine[15; 41].

At the study of Fonseca et al.[13] was investigated the potential use of orally administered marigold extract (ME) (C. officinalis extract) to prevent UV irradiation-induced oxidative stress in the skin in vitro e in vivo. This study suggested a potential applicability of this extract against UV-induced skin damage, as this extract showed relevant in vitro antioxidant activity against different radicals and prevented the UVB irradiation-induced GSH depletion in the skin of hairless mice after oral administration. Gladine et al.[42], on the other hand, observed an inhibitory effect of $C$. officinalis on lipid peroxidation in plasma of rats exposed to oxidative stress. In a very extensive study Preethi et al.[11] also measured lipid peroxidation in liver of mice fed normal mice chow. Results data of Preethi et al.[43] indicate the effectiveness of $C$. officinalis extract on enhancing the antioxidant defense mechanism thereby decreasing the burn injury.

The study of Preethi et al.[11] has shown that the Calendula extract is an antioxidant both in vitro and in vivo. Effect of free radicals on DNA can be minimized by the use of combination therapies that act at sequential steps in the DNA destruction process. Inhibition of DNA strand-breaks can reduce the mutagenicity and further carcinogenicity. Antioxidants have direct effects on transcription through antioxidant response elements present in the promoters of many genes[44].

\section{Conclusions}

We can conclude that $C$. officinalis extracts proposed for internal use in traditional medicine protects the organism against DNA damage. Taken together, it can be inferred so that aqueous or ethanolic extract of $C$. officinalis are endowed with antigenotoxic properties, and its use in pre-treatment diminishes the induction of DNA damage by an alkylant agent.

\section{ACKNOWLEDGEMENTS}

This work was supported by UNESC (Universidade do Extremo Sul Catarinense) and CNPq (Conselho Nacional de Desenvolvimento Científico e Tecnológico).

\section{REFERENCES}

[1] Jiménez-Medina, E., Garcia-Lora, A., Paco, L., Algarra, I., Collado, A., Garrido, F. (2006). A new extract of the plant Calendula of oficinalis produces a dual in vitro effect: Cytotoxic anti-tumor activity and lymphocyte activation. BMC Cancer (6): 119

[2] Tovart, R.T. (2009). Clinical approach to clinical herbal toxicity. Seminars in Diagnostic Pathology (26): 28-37

[3] Bresolin, S., Vargas, V.M.F. (1993). Mutagenic potencies of medicinal plants screened in the ames test. Phytotherapy Research (7): 260-262

[4] Fernandes, J.B.F., Vargas, V.M.F. (2003). Mutagenic and antimutagenic potential of the medicinal plants $M$. laevigata and C. xanthocarpa. Phytotherapy Research (17): 269-273

[5] Sá-Ferreira, I.C.F., Vargas, V.M.F. (1999). Mutagenicity of medicinal plant extracts in Salmonella/microsome assay. Phytotherapy Research (13): 397-400

[6] Berhow, M., Wagner, E., Vaughn, S., Plewa, M. (2000). Characterization and antimutagenic activity of soybean saponins. Mutation Research (448): 11-22

[7] Souza, A.C., Alviano, D.S., Alves, P.B., Alviano, C.S., Gattass, C.R. (2004). Melissa officinalis L. essential oil: antitumoral and antioxidant activities. Journal of Pharmacy and Pharmacology (56): 677-681

[8] Fiume, M.Z. (2001). Final Report on the safety assessment of Calendula Officinalis extract and Calendula Officinalis. International Journal of Toxicology (20): 13-20

[9] Matysik, G., Wojciak-Kosior, M., Paduch, R. (2005). The influence of Calendula officinalis flos extract on cell cultures and the chromatographic analysis of extracts. Journal of Pharmaceutical and Biomedical Analysis (38): 285-292

[10] Kishimoto, S., Maoka, T., Sumitomo, K., Ohmiya, A. (2005). Analysis of carotenoid composition in petals of calendula (Calendula officinalis L.). Bioscience, Biotechnology, and Biochemistry (69): 2122-2128

[11] Preethi, K.C., Kuttan, G., Kuttan, R. (2006). Antioxidant potential of an extract of Calendula officinalis flowers in vitro and in vivo. Pharmaceutical Biology (44): 691-697

[12] Ćetković, G.S., Djilas, S.M., Canadanovic-Brunet, J.M., Tumbas, V.T. (2004). Antioxidant properties of marigold extracts. Food Research International (37): 643-650

[13] Fonseca, Y.M., Catini, C.D., Vicentini, F.T.M.C., Nomizo, A., Gerlach, R.F., Fonseca, M.J.V. (2010). Protective effect of Calendula officinalis extract against UVB-induced oxidative stress in skin: Evaluation of reduced glutathione levels and matrix metalloproteinase secretion. Journal of Ethnopharmacology (127): 596-601

[14] Frankic, T., Salobir, K., Salobir, J. (2008). The comparison of in vivo antigenotoxic and antioxidative capacity of two propylene glycol extracts of Calendula officinalis (marigold) and vitamin E in young growing pigs. Journal of Animal Physiology and Animal Nutrition (41): 1-7

[15] Pérez-Carreón, J.I., Cruz-Jiménez, G., Licea-Veja, J.A., Popoca, E.A., Fazenda, S.F., Villa-treviño, S. (2002). Genotoxic and anti-genotoxic properties of Calendula officinalis extracts in rat liver cell cultures trated with diethylnitrosa- 
mine. Toxicology in Vitro (16): 253-258

[16] Ramos, A., Edreira, A., Vizoso, A., Betancourt, J., Lopez, M., Decalo, M. (1998). Genotoxicity of an extract of Calendula officinalis L. Journal of Ethnopharmacology (61): 49-55

[17] Farmacopéia Brasileira. (2001). Farmacopéia Brasileira. Atheneu, São Paulo. pp. 1320

[18] Lagarto, A., Bueno, V., Guerra, I., Valdés, O., Veja, Y., Torres, L. (2011). Acute and subchronic oral toxicities of Calendula officinalis extract in Wistar rats. Experimental and Toxicologic Pathology (63): 387-391

[19] Harborn, J.B. (1998). Phenolic compounds. In: Harborne, J.B. (Ed), Phytochemical methods: a guide to modern techniques of plant analysis. Chapman \& Hall; United Kingdom. UK. pp. 40-106

[20] Wagner, H., Bladt, S. (2009). Plant Drug Analysis: A Thin Layer Chromatography Atlas. Springer, Germany. pp. 384

[21] Vrzoc, M., Petras, M.L. (1997). Comparison of alkaline single cell gel (Comet) and peripheral blood micronucleus assays in detecting DNA damage caused by direct and indirect acting mutagens. Mutation Research (381): 31-40

[22] Pereira, P., Tysca, D., Oliveira, P., da Silva, B.L.F., Picada, J.N., Ardenghi, P. (2005). Neurobehavioral and genotoxic aspects of rosmarinic acid. Pharmacological Research (52): 199-203

[23] Azevedo, L., Lima, P.L.A., Gomes, J.C., Stringheta, P.C., Ribeiro, D.A., Salvadori, D.M.F. (2007). Differential response related to genotoxicity between eggplant (Solanum melanogena) skin aqueous extract and its main purified anthocyanin (delphinidin) in vivo. Food and Chemical Toxicology (45): 852- 858

[24] Mavournin, K.H., Blakey, D.H., Cimino, M.C., Salamone, M.F., Heddle, J.A. (1990). The in vivo micronucleus assay in mammalian bone marrow and peripheral blood. A report of the U.S. Environmental Protection Agency Gene-Tox Program. Mutatation Research (232): 29-80

[25] Singh, N.P., McCoy, M.T., Tice, R.R., Schneider, E.L. (1988). A simple technique for quantification of low levels of DNA damage in individual cells. Experimental Cell Research (175): 184-191

[26] Villela, I.V., Oliveira, L.M.O., Silva, J., Henriques, J.A.P. (2006). DNA damage and repair in haemolymph cells of golden mussel (Limnoperna fortunei) exposed to environmental contaminants. Mutation Research (605): 78-86

[27] Collins, A., Dusinska, M., Franklin, M., Somorosyska, M., Petroyska, H., Duthie, S., Fillion, L., Panyotidis, M., Raslová, K., Vaughan, N. (1997). Comet assay in human biomonitoring studies: reliability, validation, and applications. Environmental and Molecular Mutagenesis (30): 139-146

[28] Waters, M.D., Brady, A.L., Stack, H.F., Brockman, H.E. (1990). Antimutagenicity profiles for some model compounds. Mutation Research (238): 57-85

[29] Azevedo, L., Gomes, J.C., Stringheta, P.C., Gontijo, A.M.M.C., Padovani, C.R., Ribeiro, L.R., Salvadori, D.M.F. (2003). Black bean (Phaseolus vulgaris L.) as a protective agent against DNA damage in mice. Food and Chemical Toxicology (41): 1671-1676
[30] Brown, D.J., Dattner, A.M. (1998). Phytotherapeutic approaches to common dermatologic conditions. Archives of Dermatology (134): 1401-1404

[31] Della-Loggia, R., Tubaro, A., Sosa, S., Becker, H., Saar, S., Issac, O. (1994). The role of triterpenoids in the topical anti-inflammatory activity of Calendula officinalis flowers. Plant Medicine (60): 516-520

[32] Dumenil, G., Chemli, R., Balausard, G. (1980). Evaluation of antibacterial properties of Calendula officinalis flowers and mother homeopathic tinctures of Calendula officinalis. Annales Pharmaceutiques Fran (38): 493-499

[33] Kasiram, K., Sakharkar, P.R., Patil, A.T. (2000). Antifungal activity of Calendula officinalis. Indian Journal of Pharmaceutical Sciences (6): 464-466

[34] Barbour, E.K., Sagherian, V., Talhouk, S., Talhouk, R., Farran, M.T., Sleiman, F.T., Harakeh, S. (2004). Evaluation of homeopathy in broiler chickens exposed to live viral vaccines and dministered Calendula officinalis extract. Medical Science Monitor (10): 281-285

[35] Boucaud-Maitre, Y., Algernon, O., Raynaud, J. (1988). Cytotoxic and antitumoral activity of Calendula officinalis extracts. Pharmazie (43): 220-221

[36] Khalil, M.Y., Moustafa, A.A., Naguib, N.Y. (2007). Growth, phenolic compounds and antioxidant activity of some medicinal plants grown under organic farming conditions. World Journal of Agricultural Sciences (3): 451-457

[37] Laughton, M.J., Halliwell, B., Evans, P.J., Hoult, J.R. (1989). Antioxidant and pro-oxidant actions of plant phenolics quercetin, gossypol and myricetin. Effects on lipid peroxidation, hidroxil radical generation and bleomycin dependant DNA damage. Biochemical Pharmacology (38): 2859-2865

[38] Duarte-Silva, I., Gaspar, J., Gomes-da-Costa, G., Rodrıguez, A.S., Laires, A., Rueff, J. (2000). Chemical features of flavonols effecting their genotoxicity. Potential implications in their use as therapeutical agents. Chemico-Biological Interactions (124): 29-51

[39] Bakkali, F., Averbeck, S., Averbeck, D., Zhiri, A., Idaomar, M. (2005). Cytotoxicity and gene induction by some essential oils in the yeast Saccharomyces cerevisiae. Mutation Research (585): 1-13

[40] Re, T.A., Mooney, D., Antignac, E., Dufour, E., Bark, I., Srinivasan, V., Nohynek, G. (2009). Application of the threshold of toxicological concern approach for the safety evaluation of calendula flower (Calendula officinalis) petals and extracts used in cosmetic and personal care products. Food and Chemical Toxicology (47): 1246-1254

[41] Barajas-Farias, L.M., Pérez-Carreón, J.I., Arce-Popoca, E., Fattel-Fazenda, S., Alemán-Lazarini, L., Hernandez-García, S., Salcido-Neyoy, M., Cruz-Jime nez, F.G., Camacho, J., Villa-Trevinó, S. (2006). A dual and opposite effect of $\mathrm{Ca}$ lendula officinalis flower extract: chemoprotector and promoter in a rat hepatocarcinogenesis model. Plant Medicine (72): 217-221

[42] Gladine, C., Morand, C., Rock, E., Bauchart, D., Durand, D. (2007). Plant extracts rich in polyphenols (PERP) are efficient antioxidants to prevent lipoperoxidation in plasma lipids from animals fed n-3 PUFA supplemented diets. Animal Feed Science and Technology (136): 281-296 
[43] Preethi, K.C., Kuttan, R. (2008). Effect of Calendula officinalis Flower Extract on Acute Phase Proteins, Antioxidant Defense Mechanism and Granuloma Formation During Thermal Burns. Journal of Clinical Biochemistry and Nutri- tion (43): 58-64

[44] Palmer, H.J., Paulson, E.K. (1997). Reactive oxygen species and antioxidants in signal transduction and gene expression. Nutrition Reviews (55): 353-361 